Mijić, A., Liović I., Sudarić, A., Duvnjak, T., Jug, D., Kranjac, D., Jovović, Z., Markulj Kulundžić, A. (2021): Status and perspectives of sunflower production in Croatia. Agriculture and Forestry, 67 (1): 35-45.

DOI: 10.17707/AgricultForest.67.1.03

Anto MIJIĆ', Ivica LIOVIĆl, Aleksandra SUDARIĆ', Tomislav DUVNJAK ${ }^{1}$, Danijel JUG ${ }^{2}$, David KRANJAC ${ }^{2}$, Zoran JOVOVIĆ ${ }^{3}$, Antonela MARKULJ KULUNDŽIĆ ${ }^{\prime}$

\title{
STATUS AND PERSPECTIVES OF SUNFLOWER PRODUCTION IN CROATIA
}

\section{SUMMARY}

Sunflower, along with soybean and oilseed rape, is a very important oilseed crop in Croatia. In the period 1999-2018, it was grown on average of 32,741 ha with an average grain yield of $2.54 \mathrm{t} \mathrm{ha}^{-1}$. The largest area under sunflower was in 1999 (49,769 ha) while the highest grain yield was achieved in $2013\left(3.20 \mathrm{t} \mathrm{ha}^{-1}\right)$. In general, sunflower production is characterized by significant variations in areas and grain yields, due to number of reasons: agroecological conditions in previous growing season, prices of raw materials and repurchase, incentive and support system, applied technology and knowledge of the producers. However, in the last few years, there has been a slight increase in the areas and sunflower grain yield. Agroecological conditions, choice of hybrids, the possibility of crop rotation expansion, high grain yields in relation to almost all EU countries, processing capacities and repurchase security are in favour of the possibility of more intensive increase of areas and sunflower grain yield in Croatia.

Key words: sunflower hybrids, production, agroecological conditions, grain yield

\section{INTRODUCTION}

Agriculture is a strategic part of the economy in Croatia. In the total mainland area, agricultural area in 2017 was 26.4 percent or 1,496,663 ha. Arable areas and gardens dominated with 815,323 ha (54.5 percent), followed by permanent grasslands with 607,555 ha (40.6 percent), while orchards, vineyards, olive groves, vegetable gardens, nurseries, etc. were significantly lower (4.9 percent). Of the total agricultural area, cereals are sown on 461,483 ha or 30.8 percent, and oilseeds on 170,901 ha or 11.4 percent. Soybean is the most

\footnotetext{
${ }^{1}$ Anto Mijić (corresponding author: anto.mijic@poljinos.hr), Ivica Liović, Aleksandra Sudarić, Tomislav Duvnjak,Antonela Markulj Kulundžić, Agricultural Institute Osijek, Južno predgrađe 17, 31000 Osijek, CROATIA

${ }^{2}$ Danijel Jug, David Kranjac Josip, Juraj Strossmayer University of Osijek, Faculty of Agrobiotechnical Sciences Osijek, Vladimira Preloga 1, 31000 Osijek, CROATIA

${ }^{3}$ Zoran Jovović, University of Montenegro, Biotechnical faculty, Mihaila Lalića 1, 81000, Podgorica, MONTENEGRO

Notes: The authors declare that they have no conflicts of interest. Authorship Form signed online. 
represented oilseed and is sown on 85,133 ha, followed by oilseed rape with 48,616 ha, while sunflower is represented with 37,152 ha (Croatian Bureau of Statistics, 2020). Sunflower production in Croatia has a long tradition. As in other European countries, the sunflower was originally grown as an ornamental plant. In the second half of the 19th century, it became interesting as a plant for oil production. In Croatia, it began to expanding with the construction of oil factories in Zagreb and Čepin in the mid-1930s. Until the appearance of Russian varieties, mainly seeds of local populations were used for sowing, but also varieties created in institutes in Zagreb and Novi Sad (Krizmanić, 2012). They were characterized by high susceptibility to biotic and abiotic stresses which usually resulted in low yields. At the end of the 1950s, varieties from the former USSR (Peredovik, VNIIMK 8931, Smena, etc.) were introduced, which showed slightly higher grain yield and oil content. The dominant problem of sunflower varieties in that period was its susceptibility to diseases, primarily downy mildew, black stem and white rot. Therefore, after increase in production areas under sunflower, due to the appearance of the diseases, they decreased again (Vratarić, 2004). With the introduction of hybrids in the second half of the 1970s, sunflower production began to stabilize. The reasons for this are the advantages of hybrids compared to varieties: more uniform growth, and thus more successful application of agrotechnical measures, lower and thinner but stronger stems, shorter vegetation, better resistance to lodging, drought, diseases and pests, and lastly, higher grain yield and oil content. Although these hybrids had showed a certain susceptibility to the parasite Diaporthe (Phomopsis) helianthi, sunflower breeders solved this by incorporating genetic tolerance so that hybrids are still sown today.

The aim of this investigation is to analyze the production and yields level of sunflower seed in Croatia over the past 20-year period (from 1999 to 2018) in terms of impact of weather conditions (mainly precipitation and air temperature) on sunflower cultivation and the perspective and possibilities of expanding sunflower production in the future.

\section{MATERIAL AND METHODS}

The paper uses data from the Croatian Meteorological and Hydrological Service, the Statistical Yearbook of the Republic of Croatia and the FAOSTAT database for the period from 1999 to 2018. The monitored time period was divided into five-year periods.

The analysis included: weather conditions (precipitation and air temperature), rain factor (RFm) according to Gračanin (1950) and areas with sunflower grain yields. Data of precipitation and air temperature refer to the Osijek locality (Osijek-Baranja County) which is the most represented in terms of areas under sunflower in Croatia. According to humidity, RFm classifies the months into: perarid (pa, less than 1.6), arid (a, $1.7-3.3$ ), semiarid (sa, $3.4-5.0$ ), semihumid (sh, $5.1-6.6$ ), humid (h, $6.6-13.3$ ) and perhumid (ph, more than 13.3). 


\section{RESULTS AND DISCUSSION}

The results shown in Table 1 refer to precipitation amounts.

Table 1. Monthly precipitation ( $\mathrm{mm}$ ) for Osijek

\begin{tabular}{|c|c|c|c|c|c|c|c|c|}
\hline Year & $\mathrm{I}-\mathrm{III}{ }^{*}$ & IV & $\mathrm{V}$ & VI & VII & VIII & IX & $\begin{array}{l}\text { I- } \\
\text { IX* }\end{array}$ \\
\hline 1999 & 124 & 45 & 89 & 150 & 95 & 74 & 51 & 628 \\
\hline 2000 & 73 & 28 & 26 & 10 & 63 & 5 & 23 & 228 \\
\hline 2001 & 181 & 72 & 60 & 240 & 77 & 7 & 195 & 832 \\
\hline 2002 & 69 & 64 & 135 & 37 & 59 & 84 & 82 & 530 \\
\hline 2003 & 87 & 12 & 18 & 44 & 60 & 42 & 51 & 314 \\
\hline Mean $(1999-2003)$ & 107 & 44 & 66 & 96 & 71 & 42 & 80 & 506 \\
\hline 2004 & 141 & 137 & 65 & 80 & 44 & 107 & 42 & 616 \\
\hline 2005 & 156 & 55 & 51 & 110 & 171 & 238 & 75 & 856 \\
\hline 2006 & 134 & 87 & 79 & 78 & 15 & 134 & 11 & 538 \\
\hline 2007 & 148 & 3 & 56 & 33 & 27 & 45 & 65 & 377 \\
\hline 2008 & 120 & 49 & 67 & 76 & 68 & 47 & 82 & 509 \\
\hline Mean $(2004-2008)$ & 140 & 66 & 63 & 76 & 65 & 114 & 55 & 579 \\
\hline 2009 & 115 & 19 & 39 & 63 & 14 & 61 & 10 & 321 \\
\hline 2010 & 165 & 71 & 121 & 234 & 32 & 111 & 108 & 842 \\
\hline 2011 & 79 & 19 & 81 & 50 & 74 & 5 & 16 & 324 \\
\hline 2012 & 87 & 46 & 94 & 68 & 48 & 4 & 32 & 379 \\
\hline 2013 & 231 & 45 & 119 & 63 & 37 & 33 & 124 & 652 \\
\hline Mean $(2009-2013)$ & 135 & 40 & 91 & 96 & 41 & 43 & 58 & 504 \\
\hline 2014 & 123 & 81 & 161 & 91 & 66 & 54 & 69 & 645 \\
\hline 2015 & 181 & 13 & 113 & 17 & 26 & 106 & 41 & 497 \\
\hline 2016 & 204 & 40 & 63 & 100 & 111 & 72 & 43 & 633 \\
\hline 2017 & 167 & 50 & 51 & 45 & 64 & 30 & 80 & 487 \\
\hline 2018 & 215 & 21 & 27 & 127 & 132 & 36 & 27 & 585 \\
\hline Mean $(2014-2018)$ & 178 & 41 & 83 & 76 & 80 & 60 & 52 & 570 \\
\hline Mean $(1999-2018)$ & 140 & 48 & 76 & 86 & 64 & 65 & 61 & 540 \\
\hline Minimum & 69 & 3 & 18 & 10 & 14 & 4 & 10 & 228 \\
\hline Maximum & 231 & 137 & 161 & 240 & 171 & 238 & 195 & 856 \\
\hline Variability & 162 & 134 & 143 & 230 & 157 & 234 & 185 & 628 \\
\hline
\end{tabular}


Table 2. Mean monthly air temperature $\left({ }^{\circ} \mathrm{C}\right)$ for Osijek

\begin{tabular}{|c|c|c|c|c|c|c|c|c|}
\hline Year & I - III & IV & V & VI & VII & VIII & IX & IV - IX \\
\hline 1999 & 3.2 & 12.6 & 17.3 & 20.3 & 21.9 & 21.3 & 18.8 & 18.7 \\
\hline 2000 & 3.2 & 14.8 & 18.4 & 22.4 & 21.7 & 23.7 & 16.7 & 19.6 \\
\hline 2001 & 5.6 & 10.8 & 18.4 & 18.2 & 21.6 & 22.7 & 14.9 & 17.8 \\
\hline 2002 & 4.7 & 11.2 & 18.6 & 21.1 & 22.3 & 20.9 & 15.4 & 18.3 \\
\hline 2003 & 0.2 & 11.3 & 20.0 & 24.2 & 22.1 & 23.6 & 15.9 & 19.5 \\
\hline $\begin{array}{c}\text { Mean } \\
(1999-2003)\end{array}$ & 3.4 & 12.1 & 18.5 & 21.2 & 21.9 & 22.4 & 16.3 & 18.8 \\
\hline 2004 & 2.2 & 11.7 & 14.6 & 19.2 & 21.5 & 21.0 & 15.5 & 17.3 \\
\hline 2005 & 0.3 & 11.5 & 17.0 & 19.5 & 21.6 & 19.3 & 17.1 & 17.7 \\
\hline 2006 & 1.7 & 12.7 & 16.2 & 20.1 & 23.5 & 19.2 & 17.8 & 18.3 \\
\hline 2007 & 6.8 & 13.3 & 18.3 & 22.3 & 23.8 & 22.2 & 14.5 & 19.1 \\
\hline 2008 & 4.6 & 12.5 & 18.1 & 21.5 & 21.8 & 21.8 & 15.6 & 18.6 \\
\hline $\begin{array}{c}\text { Mean } \\
(2004-2008) \\
\end{array}$ & 3.1 & 12.3 & 16.8 & 20.5 & 22.4 & 20.7 & 16.1 & 18.2 \\
\hline 2009 & 2.7 & 14.6 & 18.3 & 19.2 & 23.2 & 22.9 & 19.1 & 19.6 \\
\hline 2010 & 2.5 & 12.4 & 16.5 & 20.4 & 23.2 & 21.7 & 15.6 & 18.3 \\
\hline 2011 & 2.7 & 13.2 & 16.7 & 20.8 & 22.2 & 23.0 & 20.3 & 19.4 \\
\hline 2012 & 2.3 & 12.5 & 16.9 & 22.5 & 24.8 & 24.1 & 18.9 & 20.0 \\
\hline 2013 & 3.4 & 13.1 & 16.7 & 20.0 & 22.9 & 22.9 & 15.9 & 18.6 \\
\hline $\begin{array}{c}\text { Mean } \\
(2009-2013)\end{array}$ & 2.7 & 13.2 & 17.0 & 20.6 & 23.3 & 22.9 & 18.0 & 19.2 \\
\hline 2014 & 6.3 & 13.2 & 16.1 & 20.5 & 21.9 & 20.8 & 17.0 & 18.3 \\
\hline 2015 & 4.3 & 12.1 & 17.8 & 20.8 & 24.6 & 23.7 & 17.9 & 19.5 \\
\hline 2016 & 5.1 & 13.1 & 16.5 & 21.0 & 22.8 & 20.6 & 18.1 & 18.7 \\
\hline 2017 & 2.9 & 11.3 & 17.5 & 22.4 & 23.4 & 23.7 & 16.1 & 19.1 \\
\hline 2018 & 3.2 & 16.5 & 20.1 & 21.0 & 22.1 & 23.6 & 17.4 & 20.1 \\
\hline $\begin{array}{c}\text { Mean } \\
(2014-2018)\end{array}$ & 4.3 & 13.2 & 17.6 & 21.1 & 23.0 & 22.5 & 17.3 & 19.1 \\
\hline $\begin{array}{c}\text { Mean } \\
(1999-2018)\end{array}$ & 3.4 & 12.7 & 17.5 & 20.9 & 22.7 & 22.2 & 16.8 & 18.8 \\
\hline Minimum & & 10.8 & 14.6 & 18.1 & 21.5 & 19.2 & 14.5 & 17.3 \\
\hline Maximum & & 16.5 & 20.1 & 24.2 & 24.8 & 24.1 & 20.3 & 20.1 \\
\hline Variability & & 5.7 & 5.5 & 6.1 & 3.3 & 4.9 & 5.8 & 2.8 \\
\hline
\end{tabular}

In summary, in the period from January to September the most precipitation fell in $2005(856 \mathrm{~mm})$, then in $2010(842 \mathrm{~mm})$ and $2001(832 \mathrm{~mm})$, and least in $2000(228 \mathrm{~mm})$, then in $2003(314 \mathrm{~mm}), 2009(321 \mathrm{~mm})$ and 2011 
(324 mm), which indicates enormous differences in the amount of precipitation between years. The difference in the amount of precipitation for the same month in different years is also evident. Good examples of precipitation variation are August 2012 and 2005 (4 mm and $238 \mathrm{~mm}$ ) as well as June 2000 and 2001 (10 $\mathrm{mm}$ and $240 \mathrm{~mm}$ ).

Differences are also evident for air temperatures (Table 2). The average temperature refers to temperatures in the growing season (April to September). The lowest temperatures were determined in $2004\left(17.3^{\circ} \mathrm{C}\right)$, followed by 2005 $\left(17.7^{\circ} \mathrm{C}\right)$ and $2001\left(17.8^{\circ} \mathrm{C}\right)$, and the highest in $2018\left(20.1^{\circ} \mathrm{C}\right)$, and then 2012 $\left(20.0^{\circ} \mathrm{C}\right)$. Even more pronounced are the differences between individual months in different years that range from 5 to $6^{\circ} \mathrm{C}$ (the difference between the maximum and minimum mean monthly temperatures for the same month). Based on fiveyear averages, a slight upward trend in average temperatures by months can be observed (Table 2). Increasingly, the occurrence of high daily maximum temperatures, but also fluctuations in weather parameters on a daily and weekly basis (Mijić et al., 2017), which can be expected in the future as well (Jug et al., 2018). This is supported by the research of Debaeke et al. (2017) who point to increasingly frequent weather changes that are characterized by: higher temperatures, elevated $\mathrm{CO}_{2}$ concentrations in the atmosphere, the occurrence of weather extremes, and water scarcity in agriculture.

Aware of the fact that precipitation and air temperature, as environmental factors, have an important role in the growth and development of every plant species, including sunflower, we can understand the complexity and demanding work of producers and breeders, creators of sunflower hybrids. Achieving the optimum of agronomic traits in a wide range of different agroecological conditions is objectively an extremely complex process that requires a lot of knowledge. Numerous authors have written about the influence of precipitation and temperature on the most important agronomic traits of sunflower (Šimić et al., 2008; Černý et al., 2011, 2013; Mijić et al., 2012, 2017.; Černý and Veverkova, 2012; González et al., 2013; Milošević et al., 2015; Liović et al., 2017; Jocković et al., 2019).

\section{Rain factor according to Gračanin (RFm)}

The relationship between precipitation and air temperature and their quantification can be seen through calculation of the rain factor according to Gračanin (RFm). Monthly averages of this factor, which refer to the twenty-year period, indicate that months in the vegetation period are perarid, semiarid and arid. The exceptions are 2005 and 2010, which had a higher degree of humidity compared to other years (Table 3). However, analyzing the five-year results, and in particular, the individual values of the rain factor, a wide range from peraridity to humidity was obtained. In the last five-year period (2014 - 2018), the largest number of months indicates aridity, which confirms the occurrence of increasingly dry years with less precipitation and higher air temperatures. 
Table 3. Rain factor according to Gračanin (RFm)

\begin{tabular}{|c|c|c|c|c|c|c|}
\hline Year & IV & V & VI & VII & VIII & IX \\
\hline 1999 & $3.6 s a$ & $5.1 \mathrm{sh}$ & $7.4 h$ & $4.3 s a$ & $3.5 \mathrm{sa}$ & $2.7 a$ \\
\hline 2000 & $1.9 a$ & $1.4 p a$ & $0.4 p a$ & $2.9 a$ & $0.2 p a$ & $1.4 p a$ \\
\hline 2001 & $6.7 h$ & $3.3 a$ & $13.2 h$ & $3.6 s a$ & $0.3 p a$ & $13.1 h$ \\
\hline 2002 & $5.7 s h$ & $7.3 h$ & $1.8 a$ & $2.6 a$ & $4.0 \mathrm{sa}$ & $5.3 \mathrm{sh}$ \\
\hline 2003 & $1.1 p a$ & $0.9 p a$ & $1.8 a$ & $2.7 a$ & $1.8 a$ & $3.2 a$ \\
\hline Mean $(1999-2003)$ & $3.8 s a$ & $3.6 s a$ & $4.9 s a$ & $3.2 a$ & $2.0 a$ & $5.1 s h$ \\
\hline 2004 & $11.7 \mathrm{~h}$ & $4.5 s a$ & $4.2 s a$ & $2.0 a$ & $5.1 s h$ & $2.7 a$ \\
\hline 2005 & $4.8 s a$ & $3.0 a$ & $5.6 s h$ & $7.9 h$ & $12.3 h$ & $4.4 s a$ \\
\hline 2006 & $6.8 h$ & $4.9 s a$ & $3.9 s a$ & $0.6 p a$ & $7.0 p a$ & $0.6 a$ \\
\hline 2007 & $0.2 p a$ & $3.1 a$ & $1.5 p a$ & $1.1 p a$ & $2.0 a$ & $4.5 s a$ \\
\hline 2008 & $3.9 \mathrm{sa}$ & $3.7 \mathrm{sa}$ & $3.5 s a$ & $3.1 a$ & $2.2 a$ & $5.3 \mathrm{sh}$ \\
\hline Mean $(2004-2008)$ & $5.5 s h$ & $3.8 s a$ & $3.7 s a$ & $3.0 a$ & $5.7 s h$ & $3.5 \mathrm{sa}$ \\
\hline 2009 & $1.3 p a$ & $2.1 a$ & $3.3 a$ & $0.6 p a$ & $2.6 a$ & $0.5 p a$ \\
\hline 2010 & $5.7 s h$ & $7.3 h$ & $11.5 h$ & $1.4 p a$ & $5.1 s h$ & $6.9 h$ \\
\hline 2011 & $1.4 p a$ & $4.9 s a$ & $2.4 a$ & $3.3 a$ & $0.2 p a$ & $0.8 p a$ \\
\hline 2012 & $3.7 \mathrm{sa}$ & $5.6 s h$ & $3.0 a$ & $1.9 a$ & $0.2 p a$ & $1.7 a$ \\
\hline 2013 & $3.4 s a$ & $7.1 h$ & $3.2 a$ & $1.6 p a$ & $1.4 p a$ & $7.8 h$ \\
\hline Mean $(2009-2013)$ & $3.1 a$ & $5.4 s h$ & $4.7 s a$ & $1.8 a$ & $1.9 a$ & $3.5 \mathrm{sa}$ \\
\hline 2014 & $6.1 s h$ & $10.0 \mathrm{~h}$ & $4.4 s a$ & $3.0 a$ & $2.6 a$ & $4.1 \mathrm{sa}$ \\
\hline 2015 & $1.1 p a$ & $6.3 s h$ & $0.8 p a$ & $1.0 \mathrm{pa}$ & $4.5 s a$ & $2.3 a$ \\
\hline 2016 & $3.1 a$ & $3.8 \mathrm{sa}$ & $4.8 s a$ & $4.9 s a$ & $3.5 s a$ & $2.4 a$ \\
\hline 2017 & $4.4 s a$ & $2.9 a$ & $2.0 a$ & $2.7 a$ & $1.3 p a$ & $5.0 \mathrm{sa}$ \\
\hline 2018 & $1.3 p a$ & $1.3 p a$ & $6.0 \mathrm{sh}$ & $6.0 \mathrm{sh}$ & $1.5 p a$ & $1.6 p a$ \\
\hline Mean $(2014-2018)$ & $3.2 a$ & $4.9 s a$ & $3.6 s a$ & $3.5 s a$ & $2.7 a$ & $3.1 a$ \\
\hline Mean $(1999-2018)$ & $3.7 \mathrm{sa}$ & $4.3 s a$ & $4.1 s a$ & $2.7 a$ & $3.0 a$ & $3.6 s a$ \\
\hline Minimum & 0.2 & 0.9 & 0.4 & 0.6 & 0.2 & 0.5 \\
\hline Maximum & 11.7 & 10.0 & 13.2 & 7.9 & 12.3 & 13.1 \\
\hline
\end{tabular}

$* a=$ arid, $h=$ humid, $s a=$ semiarid, $s h=$ semihumid, $p a=$ perarid, $p h=$ perhumid

\section{Areas and amount of grain yield}

In the last two decades $(1999-2018)$ in Croatia, the sunflower was grown on an average of 32,741 ha with grain yield of $2.54 \mathrm{t} \mathrm{ha}^{-1}$ (Figure 1). Unfortunately, production is characterized by variations, both in terms of sown areas $(20,615-49,769 \mathrm{ha})$ and grain yields $\left(1.57-3.20 \mathrm{t} \mathrm{ha}^{-1}\right)$. The reasons for this are multiple and primarily relate to: growing conditions for sunflower in previous growing season (unfavourable agroecological conditions - this usually means less sown areas next year), prices of raw materials (fertilizer, seed, 
pesticide, fuel etc.) and repurchase, incentive and support system, applied technology and knowledge of the producers. However, it can be said that there is a slight trend of increasing area and average grain yield, and that some producers, equipped with quality machinery, often achieve yields above 4 and even $5 \mathrm{t} \mathrm{ha}^{-1}$.

As can be seen in Figure 1, the differences between the minimum and maximum grain yield are over 100 percent, i.e. the lowest grain yield was achieved in 2005 (1.57 $\left.\mathrm{t} \mathrm{ha}^{-1}\right)$, and the highest yield in $2013\left(3.20 \mathrm{t} \mathrm{ha}^{-1}\right)$. According to the research of Iljkić et al. (2019) who analyzed the six field crops sown on the largest areas in Croatia (maize, wheat, soybeans, barley, sunflower and oilseed rape), the highest variability in grain yield was found in sunflower.

The low grain yield in 2005 can be partly explained by the excessive amount of precipitation during vegetation. Namely, in addition to the large reserve of winter moisture, which proved to be very important in the production of sunflowers in our agroecological conditions, there were months with aboveaverage precipitation and lower temperatures. As can be seen from Table 3, RFm indicates semihumidity (May and June) or even humidity (July and August), which is extremely unfavourable in sunflower production. In such microclimatic conditions, sunflower plants become hypersensitive to the development of diseases. This fact is supported by the research of Duvnjak et al. (2008) who point out that the occurrence and intensity of a disease in certain years significantly reduce the grain and oil yield in Croatia. Likewise, precipitation often coincided with flowering time, and since sunflower is typically a crosspollinated, entomophilous plant, pollination success was lower. In addition, the flowering time of each hybrid is short (about ten days), which limits the visit of pollinators. In conditions of continuous, more intense precipitation, the flight of insects is smaller or even absent. Also, in conditions of increased humidity, the development of thermophilic weeds often occurs, above all ragweed (Ambrosia artemisiifolia L.), rough cocklebur (Xsantium strumarium L.) and velvetleaf (Abutilon teophrasti Med.). Weeds and cultivated plants compete for soil and air biofactors, which certainly leads to a decrease in the value of the most important agronomic traits, primarily grain and oil yields. In addition, it should be emphasized that these weeds can host various pathogens and serve as a source of inoculum and potential infection (Vrandečić et al., 2007, 2008). Weed control is one of the most critical elements in optimizing sunflower yield and quality (Smatana et al., 2014).

On the other hand, the high grain yield in 2013 is based on large winter moisture reserves and a favourable distribution of precipitation during the growing season. The values of the RFm were in the range of perarid (July and August), arid (June) and semiarid (April) with the exception of May when there was slightly more precipitation. Increased amounts of precipitation during May generally did not adversely affect the growth and development of sunflower, as it did not develop a lush vegetation mass and closed the rows. Air temperatures did not deviate significantly from the multi-year average, nor did the number of days with extremely high temperatures. 


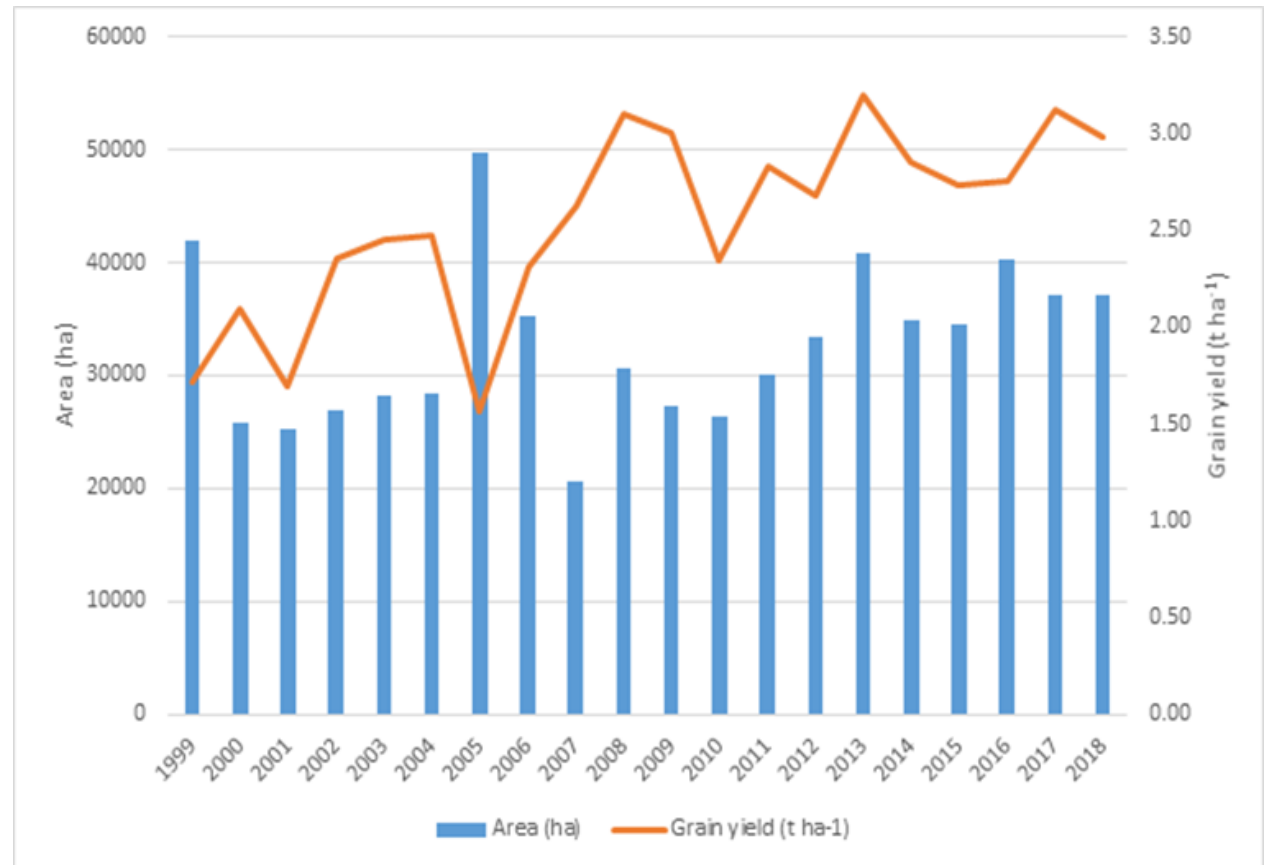

Figure 1. Sunflower growing areas and grain yields from 1999 to 2018 year in Croatia

\section{Perspectives of sunflower production}

The part of oilseeds (11.4 percent) with share of sunflower ( 2.5 percent) in the total agricultural area in Croatia is low, which indicates the need to increase this crop on our fields in the future. It should be noted that Croatia, according to the multi-year average (1999 - 2018), is the second country in terms of grain yield per ha in the European Union (FAOSTAT, 2020). The appearance of increasingly dry vegetation seasons, especially in summer with lower precipitation, higher temperatures and daily temperature maximums support the need to increase areas under sunflower. The reason lies in the fact that sunflower, of all field crops, best absorbs unwanted stress conditions (García-López et al., 2014). Sunflower has a strong and branched root of large absorbency potential and a specific anatomical structure of the stem and leaves that enables it to achieve satisfactory grain and oil yields under stressful conditions (Gadžo et al., 2011).

Sunflower is mostly grown in the eastern part of the Republic of Croatia, in Osijek-Baranja and Vukovar-Syrmia Counties, which is confirmed by the research of Zmaić et al. (2014), Iljkić et al. (2019) and Markulj Kulundžić (2019). However, on the basis of the given agroecological conditions of the rest of Croatia and the large choice of hybrids, it can be concluded that there are no obstacles for greater spreading of sunflower in other areas, especially in the remaining three Slavonian Counties: Brod-Posavina, Virovitica-Podravina and Požega-Slavonia County. Furthermore, crop rotation is a problem for a large 
number of crop producers. Most crops are grown in cycles of each three years, often two years, on the same area. The choice of sunflower, as another additional crop in the crop rotation, would certainly contribute to better efficiency of individual producers, including family farms. Sunflower leaves the field early and enables timely sowing of winter crops, leaves the soil without weeds, in good pedophysical condition, and sunflower production fits well into the optimal use of machinery (Gadžo et al., 2011).

The fact that the Oil factory Čepin, as the most important company for the repurchase and processing of oilseeds in Croatia, continuously invests in modernization and capacity widening, which is a guarantee for repurchase of this important oilseed plant in a longer period, certainly supports the spreading of sunflower areas in Croatia. At the moment, the Oil factory Čepin can repurchase and process the entire sunflower production in Croatia which can be a strongly supportive moment for additional expansion of sunflower growing.

\section{CONCLUSIONS}

Sunflower is sown in Croatia on 32,741 ha (multi-year average), mainly in its eastern lowlands part. The average grain yield is about $2.5 \mathrm{t} \mathrm{ha}^{-1}$ and the contribution of sunflower growing area in the total agricultural land is very low (2.5 percent). Production is characterized by large variations both in terms of areas as well as grain yield. In the last few years, there has been a slight increase in the growing areas and sunflower grain yield. Agroecological conditions, choice of hybrids, the possibility of crop rotation expansion, satisfactory grain yields in relation to other EU countries, processing capacities and repurchase security are in favour of the possibility of more intensive increase of areas and sunflower grain yield in Croatia.

\section{REFERENCES}

Černý I., Veverková A., Kovár M., Pačuta V., Molnárová J. (2011): Influence of temperature and moisture conditions of locality on the yield formation of sunflower (Helianthus annuus L.). Acta Universitatis Agriculturae et Silviculturae Mendelianae Brunensis, 59(6): 99-104.

Černý I. \& Veverková A. (2012): Production parameters of sunflower (Helianthus annuus L.) influenced by weather conditions and foliar application of Pentakeep-v and Atonik. Journal of Microbiology, Biotechnology and Food Sciences, 1 (special issue), 887-896.

Černý I., Veverková A., Kovár M., Mátyás M. (2013): The variability of sunflower (Helianthus annuus L.) yield and quality influenced by wheater conditions. Acta Universitatis Agriculturae et Silviculturae Mendelianae Brunensis, 61(3): 595600. DOI: 10.11118/actaun201361030595.

Debaeke P., Caadebaig P., Flenet F, Langlade N. (2017): Sunflower crop and climate change: vulnerability, adaptation, and mitigation potential from case-studies Europe. Oilseeds \& fats Crops and Lipids, 24(1), D102: 1-15. DOI: 10.1051/oc1/2016052

Croatian Meteorological and Hydrological Service. https://meteo.hr/ 
Croatian Bureau of Statistics (2020). www.dzs.hr

FAOSTAT Database (2020). http://faostat.fao.org/site/567/DesktopDefault.aspx?PageID=567\#ancor

Duvnjak T., Mijić A., Liović I., Vratarić M., Sudarić A., Krizmanić M., Vrandečić K., Ćosić J. (2008): Estimation of sunflower breeding material tolerance on Diaporthe/Phomopsis helianthi. Proceeding of 17th International Sunflower Conference. Cordoba. Spain. 143-147.

Gadžo D., Đikić M., Mijić A. (2011): Industrijsko bilje. Poljoprivredno-prehrambeni fakultet Univerziteta u Sarajevu. Bosna i Hercegovina.

García-López J., Lorite I.J., García-Ruiz R., Domínguez J. (2014): Evaluation of three simulation approaches for assessing yield of rainfed sunflower in a Mediterranean environment for climate change impact modelling. Clim. Change, 124(1-2): 147162. DOI: $10.1007 / \mathrm{s} 10584-014-1067-6$

González J., Mancuso N., Ludueña P. (2013): Sunflower yield and climatic variables. Helia, 36(58): 69-76. DOI: 10.2298/HEL1358069G

Gračanin M. (1950): Mjesečni kišni faktori i njihovo značenje u pedološkim istraživanjima. Poljoprivredna znanstvena smotra, 12: 51-66.

Iljkić D., Kranjac D., Zebec V., Varga I., Rastija M., Antunović M., Kovačević V. (2019): Stanje i perspektiva proizvodnje žitarica i uljarica u Republici Hrvatskoj. Glasnik zaštite bilja, 3: 58-67. DOI: 10.31727/gzb.42.3.9

Jocković M., Cvejić S., Jocić S., Marjanović-Jeromela A., Miladinović D., Jocković B., Miklič V., Radić V. (2019): Evaluation of sunflower hybrids in multi-environment trial (MET). Turkish Journal of Field Crops, 24(2): 202-210. DOI: $10.17557 / \mathrm{tjfc} .645276$

Jug D., Jug I., Brozović B., Vukadinović V., Stipešević B., Đurđević B. (2018): The role of conservation agriculture in mitigation and adaptation to climate change. Agriculture, 24(1): 35-44. DOI: 10.18047/poljo.24.1.5

Krizmanić M. (2012): Suncokret. U Oplemenjivanje poljoprivrednog bilja u Hrvatskoj. Kozumplik, Pejić (ur.), Agronomski fakultet Sveučilišta u Zagreb. Hrvatska. 77-80.

Liović I., Mijić A., Markulj Kulundžić A., Duvnjak T., Gadžo D. (2017): Utjecaj vremenskih uvjeta na urod zrna, sadržaj ulja i urod ulja novih OS hibrida suncokreta. Poljoprivreda, 23(1): 34-39. DOI: 10.18047/poljo.23.1.6

Markulj Kulundžić A. (2019): Biokemijski mehanizmi regulacije učinkovitosti fotosustava II u listovima suncokreta pod utjecajem okolišnog stresa. Doktorska disertacija. Poslijediplomski interdisciplinarni sveučilišni studij Molekularne bioznanosti. Osijek. Hrvatska.

Mijić A., Liović I., Kovačević V., Pepo P. (2012): Impact of weather conditions on variability in sunflower yield over years in eastern parts of Croatia and Hungary. Acta agronomica Hungarica, 60(4): 397-405. DOI: 10.1556/AAgr.60.2012.4.10

Mijić A., Liović I., Sudarić A., Gadžo D., Jovović Z., Jankulovska M., Markulj Kulundžić A., Duvnjak T. (2017): The effect of environment on the phenotypic expression of grain yield, oil content and oil yield in sunflower hybrids. Agriculture and Forestry, 63(1): 309-318. DOI:10.17707/AgricultForest.63.1.32

Milošević D., Savić S.M., Stojanović V., Popov-Raljić J. (2015): Effects of precipitation and temperatures on crop yield variability in Vojvodina (Serbia). Italian Journal of Agrometeorology - Rivista Italiana di Agrometeorologia, 20(3): 35-46. 
Smatana J., Macak M., Ernst D. (2014): Weed control in sunflower (Helianthus annuus L.) on the interface of agro-climatic conditions of maize and sugar beet growing region. Acta fitotechnica and zootechnica, 17(4): 115-121. DOI: 10.15414/afz.2014.17.04.115-121

Šimić B., Ćosić J., Liović I., Krizmanić M., Poštić J. (2008): The influence of weather conditions on economic characteristics of sunflower hybrids in macro experiments from 1997 to 2007. Proceedings of 17th International Sunflower Conference. Córdoba. Spain. 261-263.

Vrandečić K., Duvnjak T., Jurković D., Mijić A. (2007): Reaction of sunflower stems to inoculation with Sclerotinia sclerotiorum isolated from sunflower and Abutilon theophrasti. Cereal Research Communications, 35(2): 1317-1320.

Vrandečić K., Jurković D., Ćosić J., Riccioni L., Duvnjak T. (2008): Morphological and molecular identification of Diaporthe helianthi from Xanthium italicum. Disease Resistance and Pathology. Proceedings of the 17th International Sunflower Conference, Córdoba, Spain. 121-124.

Vratarić M. (2004): Značaj suncokreta kao kulture i proizvodnja suncokreta u svijetu i u Republici Hrvatskoj. U Suncokret Helianthus annuus L. Vratarić (ur.), Poljoprivredni institut Osijek, Hrvatska. 1-13.

Zmaić K., Sudarić T., Majdak T., Nedić I. (2014): Ekonomski rezultati proizvodnje suncokreta u Republici Hrvatskoj. Zbornik radova 49. hrvatskog $i 9$. međunarodnog simpozija agronoma, Dubrovnik, Hrvatska. 186-190. 